\title{
RANCANG BANGUN DAN IMPLEMENTASI ALAT UKUR DAN SISTEM INFORMASI PADA LISTRIK SATU FASA
}

\section{DESIGN AND IMPLEMENTATION MEASURING INSTRUMENT AND INFORMATION SYSTEMS ON SINGLE-PHASE ELECTRICAL}

\author{
Dadan Nur Ramadan ${ }^{1}$, Agus Ganda Permana ${ }^{2}$, Galuh Mardiansyah ${ }^{3}$, Dyah Puspaningrum ${ }^{4}$ \\ ${ }^{1,2,3,4}$ Prodi D3 Teknik Telekomunikasi, Fakultas Ilmu Terapan, Universitas Telkom \\ 1dadan.nr@gmail.com
}

\begin{abstract}
Abstrak
Sistem monitoring penggunaan listrik baik secara prabayar maupun pascabayar masih memiliki beberapa masalah, salah satu permasalahan yang terjadi adalah masih kurangnya pengawasan untuk mengetahui seberapa besar penggunaan listrik di suatu rumah atau suatu daerah. Untuk mengatasi permasalahan tersebut, diperlukan sebuah perangkat yang mampu mengukur parameter-parameter pada listrik arus AC (Alternating Current) satu fasa, dan menampilkannya hasilnya dalam suatu sistem informasi, sehingga penggunaan daya listrik dari setiap rumah atau daerah dapat diketahui jumlahnya.

Dengan menggunakan papan mikrokontroler Arduino Uno sebagai pengolah datanya, parameter yang dapat diukur oleh perangkat terdiri dari arus, tegangan dan daya, data pengukuran tersebut kemudian dikirim melalui jaringan wireless ke sebuah komputer server, komputer server berfungsi sebagai penyimpanan data hasil monitoring dan mengolah data tersebut menjadi sebuah informasi yang ditampilkan dalam sebuah website.

Berdasarkan hasil pengujian pada pengukuran arus didapatkan nilai kesalahan rata-rata sebesar $3,28 \%$, kesalahan rata-rata pengukuran tegangan sebesar $0,39 \%$, pada pengukuran nilai daya didapatkan nilai kesalahan rata-rata sebesar $8,82 \%$. Sedangkan pada proses pengiriman data diperoleh nilai presentase error sebesar $0.1 \%$, dan akurasi data mencapai $100 \%$.
\end{abstract}

Kata kunci: Alat ukur listrik, Sistem monitoring, Listrik Satu Fasa.

\begin{abstract}
Electricity usage monitoring system both prepaid and postpaid still have some problems, one problem is still lack of supervision to determine how much electricity usage in a home or a region. To solve that problem, we need a device that is able to measuring electrical parameters in single phase AC (Alternating Current), and displays the results in an information system, so the power consumption of each home or area can be determined.

By using Arduino Uno microcontroller board to processing data, the parameters that can be measured by the device is the current, voltage and power. Then the measurement data sent via wireless network to a server computer, the function of a computer server is to store all monitoring data and processing the data become information and displayed in a website.

Based on the test results obtained average error $3.28 \%$ for current measurement, average error $0.39 \%$ for voltage measurement, average error $8.82 \%$ for power measurement. While in the process of sending data the percentage error is $0.1 \%$, and the accuracy data reaches $100 \%$.
\end{abstract}

Keywords: Electrical Measuring Devices, Monitoring System, Single Phase Electric. 


\section{PENDAHULUAN}

Sistem pemantauan untuk konsumsi daya listrik masih memiliki kekurangan baik pada sistem listrik pascabayar maupun prabayar, sampai dengan saat ini sistem pemantauan hanya bisa dilakukan oleh pihak PT. PLN yang dilakukan secara manual, sehingga masih memungkinkan adanya kesalahan manusia dalam pemantauannya, untuk meningkatkan pemantauan penggunaan konsumsi listrik yang lebih baik dibutuhkan alat yang dapat menampilkan penggunaan daya listrik secara realtime.

Berdasarkan data dari beberapa penelitian sebelumya mengenai alat ukur pada listrik [1-2], analisa pengaruh harmonisa terhadap hasil penunjukan kwh meter digital 1 fasa [3], dan penelitian mengenai sistem pemantauan energi listrik pada bagunan secara waktu nyata berbasis web [4]. Maka penelitian ini difokuskan pada sebuah sistem yang terdiri dari alat pengukur parameter listrik satu fasa dan sistem informasi monitoring listrik, yang dapat memantau penggunaan listrik untuk skala rumah, data yang diukur oleh alat pengukuran adalah data tegangan, arus, serta daya, kemudian data tersebut akan dikirim ke sebuah komputer server, sehingga dapat dilihat secara realtime melalui sebuah sistem informasi berupa website.

Website ini mampu untuk menerima data dari beberapa alat ukur yang disimpan di beberapa rumah, serta dapat memonitoring sebuah area perumahan yang besar, sehingga memudahkan pemantauan penggunaan listrik oleh pemilik rumah ataupun PLN selaku penyedia energi listrik untuk memantau penggunaan daya pada area perumahan, dan sekaligus menjadi pembaruan dari beberapa penelitian pada pengukuran pemakaian listrik yang telah dilakukan sebelumnya.

\section{DASAR TEORI}

\subsection{Tegangan, Daya dan Arus pada Listrik AC Satu Fasa}

Pada sistem listrik DC (Direct Current), perhitungan daya dirumuskan sebagai perkalian arus listrik dengan tegangan. Sedangkan pada sistem listrik AC (Alternting Current). perhitungan daya menjadi sedikit berbeda karena melibatkan faktor daya $(\cos \varnothing)$.

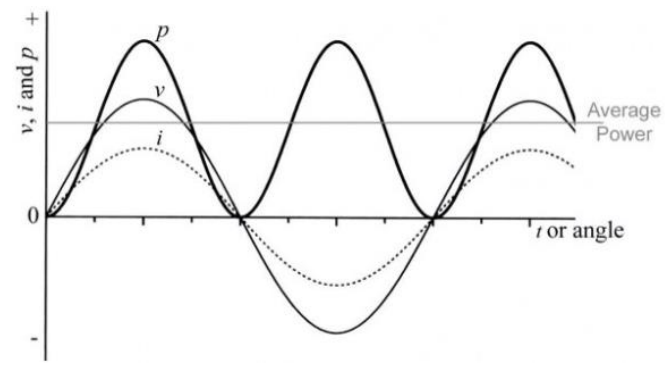

Gambar 1. Gelombang Arus, Tegangan, dan Daya Listrik AC[5]

Pada gambar diatas adalah grafik pada gelombang listrik AC dengan beban murni resistif. gelombang arus dan tegangan yang berada pada fase yang sama dan tidak ada yang saling mendahului, dengan kata lain nilai dari faktor daya $(\cos \varnothing)$ adalah 1 , dengan menggunakan rumus daya, nilai dari daya listrik memiliki nilai yang selalu positif, serta membentuk gelombang seperti pada Gambar 1.

$$
P=I \times V \times \cos \emptyset
$$

Daya reaktif (Reactive Power) adalah daya yang disuplly oleh komponen reaktif. Daya reaktif (Q) ini tidak memiliki dampak apapun dalam kerja suatu beban listrik, dengan kata lain daya reaktif ini tidak berguna bagi konsumen listrik. Satuannya adalah VAR (Volt Ampre Reactive), dirumuskan sebagai berikut; 
$\mathrm{Q}=\mathrm{V} \cdot \mathrm{I} \cdot \sin \emptyset$

$\varnothing=$ Faktor Daya

$\mathrm{V}=$ Tegangan

$\mathrm{I}=$ Arus

Daya semu (Apparent Power) adalah daya yang dihasilkan oleh perkalian antara tegangan $\mathrm{V}$ dan arus I, satunnya adalah VA, dirumuskan sebagai berikut:

$\mathrm{S}=\mathrm{V}$. I

Hubungan matematika antara tipe-tipe daya yang berbeda (Apparent Power, Active Power dan Reactive Power) dapat digambarkan dalam sebuah diagram segitiga daya.

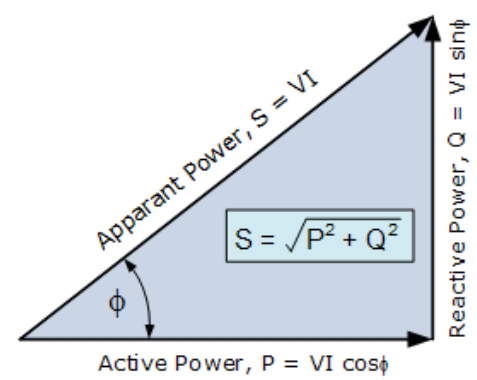

Gambar 2. Segitiga Daya[6]

Dengan menggunakan prinsip trigonometri, maka diperoleh:

$$
S^{2}=P^{2}+Q^{2}
$$

\subsection{Arduino}

Arduino adalah sebuah mikrokontroler yang bersifat open-source, hardware mikrokontroler Arduino diprogram dengan menggunakan bahasa pemrograman wiringbased yang berbasiskan syntax dan library, untuk memudahkan dalam pengembangan aplikasinya, mikrokontroler Arduino juga menggunakan Integerated Development Environment (IDE) berbasis processing [7]. Dengan melengkapi Arduino dengan sensor, aktuator, lampu, speaker dan add-on modul (Shield) atau sirkuit terintegrasi lainnya, Arduino dapat di modifikasi menjadi sebuah inti proses kontrol dari sebuah sistem.

Sensor arus yang digunakan adalah tipe SCT013-000 yang memiliki spesifikasi pengukuran arus hingga $100 \mathrm{~A}[8]$, penggunaanya dengan cara salah satu kabel dari sumber listrik bisa diklipkan dengan sensor ini, sehingga aliran arus dapat terbaca oleh sensor karena menghasilkan medan magnet yang ditangkap inti ferit yang terdapat di sensor,

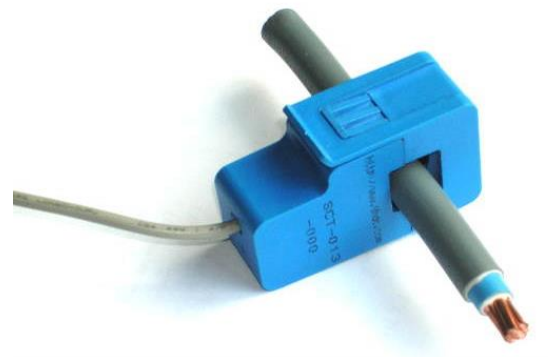

Gambar 3. Sensor Arus SCT 013-000[9]

Modul wireless yang digunakan adalah WizFi210, merupakan modul converter untuk antarmuka UART menjadi Wireless Ethernet ataupun sebaliknya, dengan fungsi tersebut, maka WIZFi210 mampu membantu peralatan elektronika yang hanya memiliki antarmuka UART agar 
dapat terhubung ke jaringan LAN secara wireless. WizFi210 mempunyai standar IEEE $802.11 \mathrm{~b} / \mathrm{g} / \mathrm{n}[10]$.

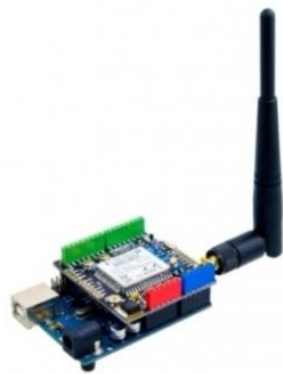

Gambar 4. Arduino uno dengan Modul Wireless WizFi210[10]

\subsection{Sistem Informasi}

Menurut Robert A. Leitch dan K. Roscoe Davis dalam buku Jogiyanto HM., (1999:11) [11], Sistem informasi adalah suatu sistem di dalam suatu organisasi yang mempertemukan kebutuhan pengolahan transaksi harian, mendukung operasi, bersifat manajerial dan kegiatan strategi dari suatu organisasi dan menyediakan pihak luar tertentu dengan laporan-laporan yang diperlukan.

\section{PERANCANGAN dan IMPELEMENTASI}

\subsection{Alat Ukur Listrik Satu Fasa}

Pada Pembuatan alat ukur listrik satu fasa ini, dibuat dua blok utama yaitu blok pengukuran dan blok sistem informasi, seperti pada Gambar 5.

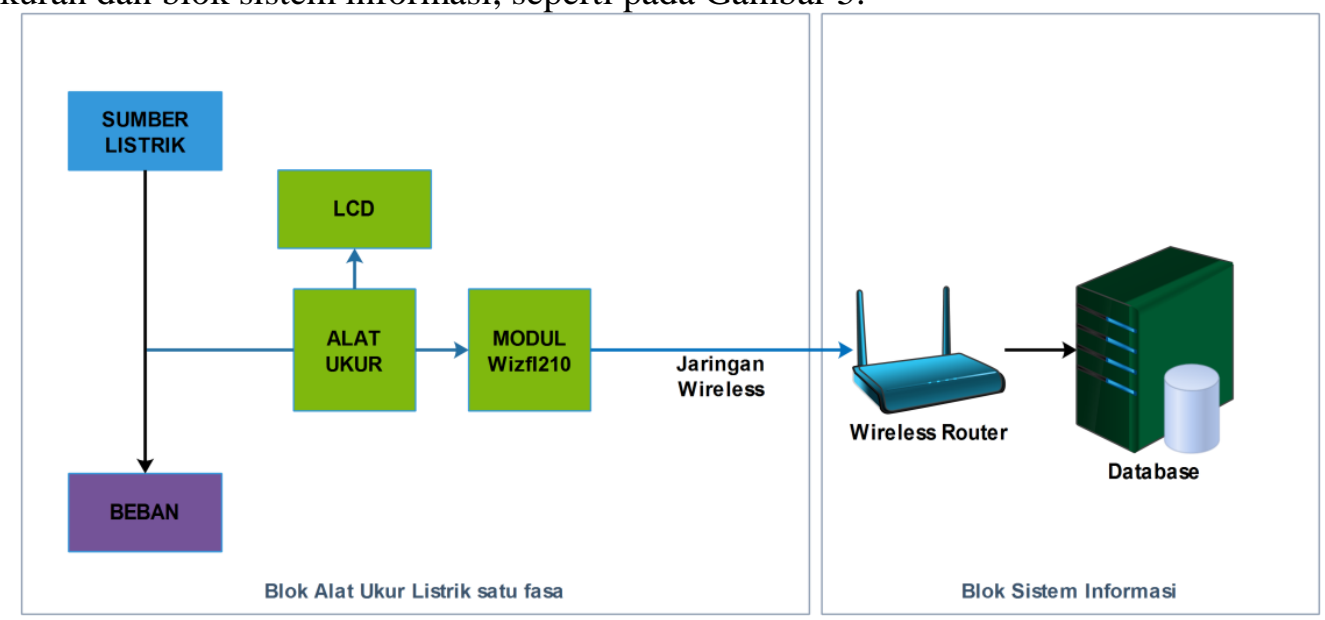

Gambar 5. Diagram Sistem Monitoring Arus Listrik

Pembuatan blok diagram pengukuran daya, terdiri dari beberapa subsistem, sebagai berikut:

1) Alat Ukur mengukur tegangan, arus, dan faktor daya pada jala-jala listrik, setiap alat ukur memiliki id yang berbeda, sehingga data yang di kirim ke komputer server tidak tertukar.

2) Database; menerima data dari perangkat alat ukur yang terdiri nilai arus, tegangan, daya dan frekuensi, dan menampilkannya dalam bentuk grafik pada suatu sistem informasi berupa website, tampilan dibedakan berdasarkan id_rumah.

3) Jaringan wireless digunakan sebagai media untuk mengirim informasi dari alat ukur ke database sistem informasi.

\subsection{Pengiriman, Validasi dan Penyimpanan Data}

Modul Shield Wifi-wizfi210 digunakan sebagai interface untuk mengirim data hasil pengukuran dari setiap alat ukur ke database pada komputer server, data yang adalah id_rumah, 
tegangan ,arus, daya dan frekuensi. Kemudian data pengukuran tersebut diterima oleh sebuah script php, yang berfungsi untuk menvalidasi data apakah id_rumah yang dikirim sesuai dengan id_rumah yang terdapat pada database, apabila id_rumah sama maka data akan diberikan data tambahan, berupa tanggal kemudiaan data akan disimpan pada database. Penambahan tanggal berfungsi sebagai identitas waktu dan tanggal dari sebuah data, hal ini bertujuan untuk mempermudah penyajian data pada saat diolah nanti.

Berikut adalah konfigurasi script php yang tersimpan pada sistem informasi, berfungsi untuk menerima dan menvalidasi data, yang dikirim dari alat ukur dan menyimpannya pada database apabila proses validasi terlewati;

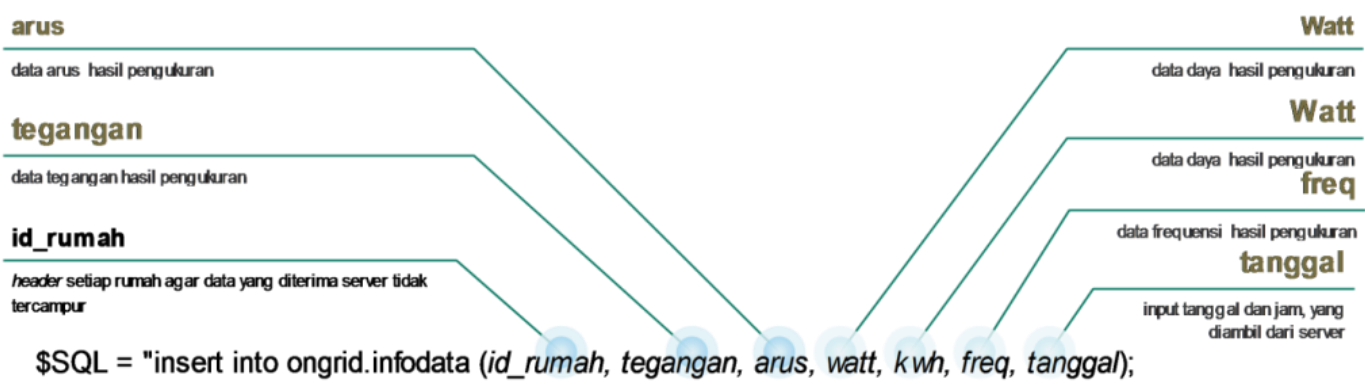

Gambar 6. script yang berfungsi untuk menyimpan data ke dalam database

\subsection{Database}

Database yang digunakan dalam pembuatan website ini mempunyai dua buah tabel yaitu tabel login, tabel infodata.

\begin{tabular}{|c|c|}
\hline$v 0$ ongrid.login & v o ongrid infodata \\
\hline e id_user : int(5) & \# id_user : int(5) \\
\hline e username : char(20) & \# id_rumah : int(5) \\
\hline (1) password : char(50) & 8 id_data : int(5) \\
\hline (i) nama : $\operatorname{char}(50)$ & \# tegangan : double \\
\hline (1) alamat: $\operatorname{char}(100)$ & (i) arus : varchar(10) \\
\hline admin : enum('O','1') & (B) frekuensi : varchar(10) \\
\hline gambar : varchar(6000) & 目 watt: varchar(10) \\
\hline & $\begin{array}{l}\text { \# kwh : float } \\
\text { @ tanggal : datetime }\end{array}$ \\
\hline
\end{tabular}

Gambar 7. Relasi Antar Tabel yang Terdapat dalam Database Ongrid

Tabel login terdiri dari id_user, username, password, nama, alamat, dan status, tabel ini digunakan untuk menyimpan data milik user maupun milik admin. Tabel berikutnya adalah tabel infodata. Tabel ini terdiri dari id_user, id_data,id_rumah, tegangan, arus, frekuensidan tanggal.

\subsection{Sistem Informasi}

Untuk mempermudah pembacaan data pada sistem informasi, maka dibuat sebuah website, menggunakan bahasa pemprograman PHP dan MySQL sebagai database. Pada website ini hak akses dibagi menjai dua yaitu admin dan pemilik rumah (user). User hanya dapat melihat hasil pengukuran pada rumah masing-masing, sedangkan admin dapat melihat seluruh data hasil pengukuran dari setiap rumah atau seluruhan rumah yang terpasang alat pengukuran, serta dapat menambah, merubah dan menghapus user, sehingga perubahan jumlah user dapat dilakukan. 


\section{WELCOME Admin}

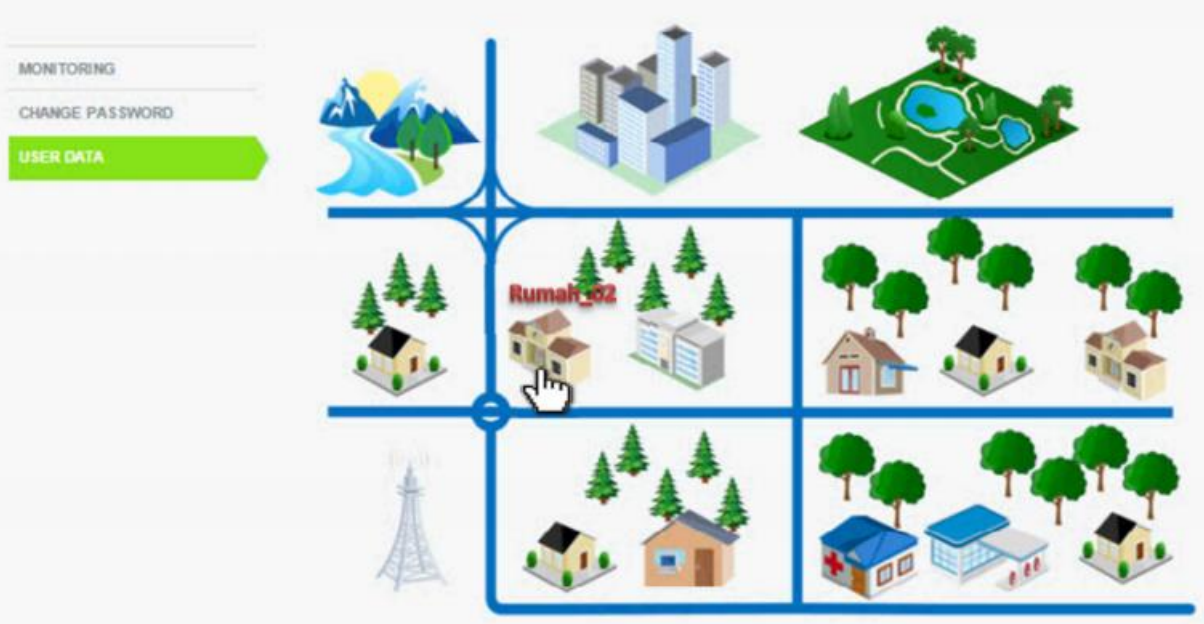

Gambar 8. Tampilan halaman Admin

Data hasil pengukuran yang sudah tersimpan didalam database, kemudian diolah dan ditampilkan dalam sebuah grafik menggunakan library highchart[12], seperti pada gambar berikut;

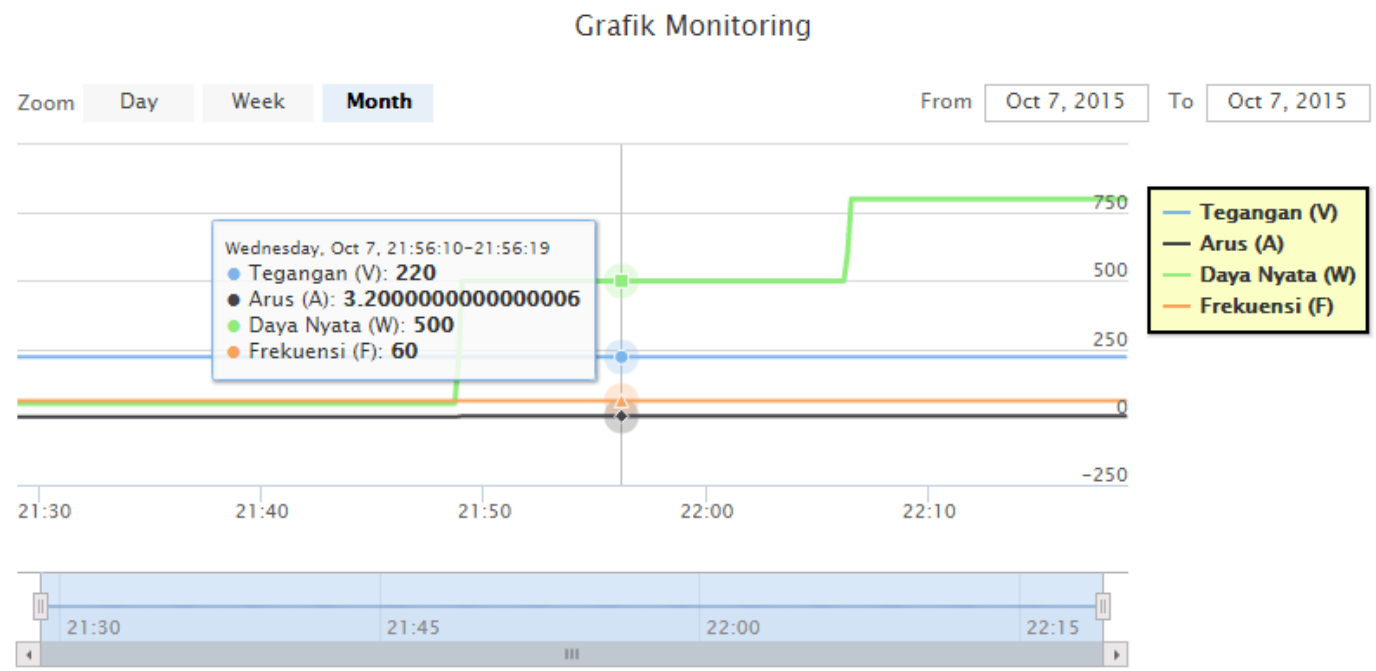

Gambar 9. Grafik Monitoring pada Sistem Informasi

Hasil pengukuran yang dapat dilihat oleh user atau admin adalah hasil pengukuran tegangan, arus, daya dan frekuensi dari setiap rumah, dan data tersebut ditampilkan dalam bentuk grafik.

\section{HASIL dan PENGUJIAN}

Pengujian setiap blok rangkaian dilakukan untuk mengetahui performansi dan mengetes rangkaian yang telah dibuat, apakah sesuai dengan perancangan atau belum. Pengujian dilakukan dengan cara memberikan beban yang berbeda-beda pada alat pengukuran, pengujian dilakukan pada pengukuran parameter listrik, pengiriman data, validasi dan tampilan pada grafik. 


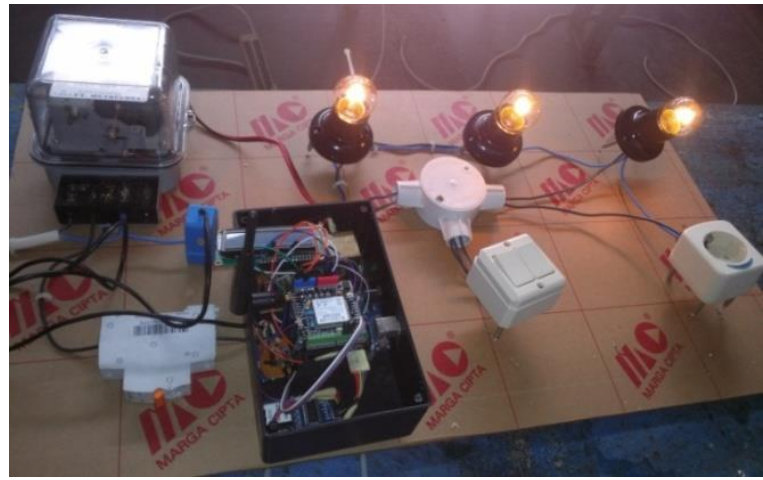

Gambar 10. Pengujian alat dengan beban Lampu

Pengujian sistem ini dilakukan untuk mengetahui kehandalan dari sistem itu sendiri. Pengujian ini sendiri dibagi menjadi 2 bagian, yakni pengujian perangkat pengukuran dan pengujian sistem informasi, pengujian perangkat pengukuran arus dan tegangan akan dilakukan dengan melakukan perbandingan antara hasil pengukuran menggunakan perangkat yang dibuat dan hasil pengukuran menggunakan multimeter, untuk pengujian nilai daya dilakukan dengan cara melihat hasil pengukuran daya menggunakan perangkat, daya yang diuji adalah daya nyata (Watt) dan daya semu (VA).

\subsection{Pengujian Arus}

Pengujian rangkaian rangkaian sensor arus bertujuan untuk mengetahui kestabilan keluaran nilai arus ketika diberi beban yang bervariasi, pengujian dilakukan dengan melakukan perbandingan, antara pengukuran arus dengan multimeter.

$\mid$ Error Value $\mid=\frac{\text { Hasil pengukuran perangkat-hasil pengukuran Multimeter }}{\text { hasil pengukuran multimeter }} \times 100 \%$

Tabel 1. Hasil Pengukuran Arus dengan menggunakan Beban

\begin{tabular}{|c|c|c|c|c|c|}
\hline No & id_rumah & $\begin{array}{c}\text { Beban yang } \\
\text { diberikan } \\
\text { (Watt) }\end{array}$ & $\begin{array}{c}\text { Nilai pada } \\
\text { perangkat (Ampere) }\end{array}$ & $\begin{array}{c}\text { Nilai pada } \\
\text { Multimeter } \\
\text { (Ampere) }\end{array}$ & $\begin{array}{c}\text { Nilai Kesalahan } \\
\text { (error value) }\end{array}$ \\
\hline $\mathbf{1}$ & 001 & 50 & 0.37 & 0.37 & $0.00 \%$ \\
\hline $\mathbf{2}$ & 001 & 50 & 0.37 & 0.37 & $0.00 \%$ \\
\hline $\mathbf{3}$ & 001 & 50 & 0.38 & 0.37 & $0.37 \%$ \\
\hline $\mathbf{4}$ & 001 & 50 & 0.37 & 0.36 & $0.36 \%$ \\
\hline $\mathbf{5}$ & 001 & 50 & 0.38 & 0.36 & $0.72 \%$ \\
\hline $\mathbf{6}$ & 002 & 500 & 2.17 & 2.15 & $6.30 \%$ \\
\hline $\mathbf{7}$ & 002 & 500 & 2.19 & 2.16 & $6.48 \%$ \\
\hline $\mathbf{8}$ & 002 & 500 & 2.19 & 2.16 & $4.32 \%$ \\
\hline $\mathbf{9}$ & 002 & 500 & 2.18 & 2.16 & $4.32 \%$ \\
\hline $\mathbf{1 0}$ & 002 & 500 & 2.18 & 2.16 & $3.63 \%$ \\
\hline $\mathbf{1 1}$ & 003 & 800 & 3.62 & 3.63 & $0.00 \%$ \\
\hline $\mathbf{1 2}$ & 003 & 800 & 3.63 & 3.63 & $7.26 \%$ \\
\hline $\mathbf{1 3}$ & 003 & 800 & 3.65 & 3.63 & $0.00 \%$ \\
\hline $\mathbf{1 4}$ & 003 & 800 & 3.64 & 3.64 & $10.89 \%$ \\
\hline $\mathbf{1 5}$ & 003 & 800 & 3.66 & 3.63 & \\
\hline
\end{tabular}

Dari tabel diatas menunjukkan bahwa nilai kesalahan pada pengujian pengukuran arus ratarata secara keseluruhan sebesar 3,28\%, nilai kesalahan pada pengujian pengukuran arus berasal dari nilai error yang dimiliki setiap komponen pada perangkat seperti resistor, kapasitor dan yang lainnya.

\subsection{Pengujian Tegangan}

Pengujian dilakukan dengan membandingkan pengukuran tegangan antara menggunakan alat yang dirancang dan pengukuran dengan menggunakan multimeter digital, pengujian pengukuran nilai tegangan dilakukan secara bersamaan. 


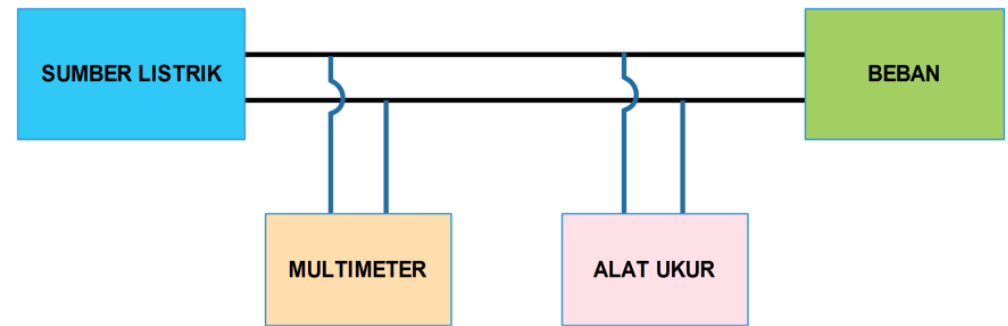

Gambar 11. Skema Pengujian Pengukuran Tegangan

Untuk pengujian pengukuran tegangan dengan dan tanpa beban didapatkan hasil pengujian sebagai berikut:

Tabel 2. Hasil Pengukuran Tegangan

\begin{tabular}{|c|c|c|c|c|c|}
\hline No & id_rumah & $\begin{array}{c}\text { Beban yang } \\
\text { diberikan } \\
\text { (Watt) }\end{array}$ & $\begin{array}{c}\text { Nilai pada } \\
\text { perangkat (Volt) }\end{array}$ & $\begin{array}{c}\text { Nilai pada } \\
\text { Multimeter (Volt) }\end{array}$ & $\begin{array}{c}\text { Nilai Kesalahan } \\
\text { (error value })\end{array}$ \\
\hline $\mathbf{1}$ & 001 & 0 & 220 & 220 & $0.00 \%$ \\
\hline $\mathbf{2}$ & 001 & 0 & 220 & 221 & $0.45 \%$ \\
\hline $\mathbf{3}$ & 001 & 0 & 220 & 221 & $0.45 \%$ \\
\hline $\mathbf{4}$ & 001 & 0 & 219 & 220 & $0.45 \%$ \\
\hline $\mathbf{5}$ & 001 & 0 & 219 & 220 & $0.45 \%$ \\
\hline $\mathbf{6}$ & 002 & 50 & 220 & 221 & $0.45 \%$ \\
\hline $\mathbf{7}$ & 002 & 50 & 219 & 221 & $0.90 \%$ \\
\hline $\mathbf{8}$ & 002 & 50 & 219 & 220 & $0.45 \%$ \\
\hline $\mathbf{9}$ & 002 & 50 & 220 & 221 & $0.45 \%$ \\
\hline $\mathbf{1 0}$ & 002 & 50 & 220 & 221 & $0.45 \%$ \\
\hline $\mathbf{1 1}$ & 003 & 500 & 220 & 220 & $0.00 \%$ \\
\hline $\mathbf{1 2}$ & 003 & 500 & 219 & 221 & $0.90 \%$ \\
\hline $\mathbf{1 3}$ & 003 & 500 & 219 & 221 & $0.90 \%$ \\
\hline $\mathbf{1 4}$ & 003 & 500 & 220 & 220 & $0.00 \%$ \\
\hline $\mathbf{1 5}$ & 003 & 500 & 220 & 220 & $0.00 \%$ \\
\hline
\end{tabular}

Dari tabel diatas dapat disimpulkan, untuk pengukuran tegangan menggunakan perangkat pada jaringan listrik tanpa beban memiliki nilai kesalahan rata-rata sebesar 0,39\%.

\subsection{Pengujian Daya}

Pengujian pengukuran nilai daya dilakukan untuk mengetahui kestabilan perangkat dalam menghitung besarnya daya listrik yang digunakan pada suatu jaringan listrik, nilai daya yang diukur ada dua macam daya yang terdiri dari daya semu (VA) dan daya nyata (W).

Tabel 3. Hasil Pengukuran Daya Semu dan Nyata

\begin{tabular}{|c|c|c|c|c|c|}
\hline No & id_rumah & $\begin{array}{c}\text { Beban yang } \\
\text { diberikan } \\
\text { (Watt) }\end{array}$ & Daya Semu (VA) & Daya Nyata (W) & $\begin{array}{c}\text { Nilai Kesalahan } \\
\text { (error value })\end{array}$ \\
\hline $\mathbf{1}$ & 001 & 50 & 70 & 67 & $4.48 \%$ \\
\hline $\mathbf{2}$ & 001 & 50 & 71 & 68 & $4.41 \%$ \\
\hline $\mathbf{3}$ & 001 & 50 & 69 & 67 & $2.99 \%$ \\
\hline $\mathbf{4}$ & 001 & 50 & 70 & 68 & $2.94 \%$ \\
\hline $\mathbf{5}$ & 001 & 50 & 70 & 67 & $2.48 \%$ \\
\hline $\mathbf{6}$ & 002 & 500 & 512 & 501 & $1.99 \%$ \\
\hline $\mathbf{7}$ & 002 & 500 & 513 & 503 & $1.79 \%$ \\
\hline $\mathbf{8}$ & 002 & 500 & 511 & 502 & $1.99 \%$ \\
\hline $\mathbf{9}$ & 002 & 500 & 512 & 502 & $1.79 \%$ \\
\hline $\mathbf{1 0}$ & 002 & 500 & 512 & 503 & $0.87 \%$ \\
\hline $\mathbf{1 1}$ & 003 & 800 & 808 & 801 & $0.87 \%$ \\
\hline $\mathbf{1 2}$ & 003 & 800 & 810 & 803 & $0.62 \%$ \\
\hline $\mathbf{1 3}$ & 003 & 800 & 808 & 803 & $1.00 \%$ \\
\hline $\mathbf{1 4}$ & 003 & 800 & 809 & 801 & $1.12 \%$ \\
\hline $\mathbf{1 5}$ & 003 & 800 & 810 & 801 & \\
\hline
\end{tabular}


Dari tabel diatas didapatkan nilai daya nyata (W) terhadap dengan Beban, maka dipeloleh nilai rata-rata sebesar $8,82 \%$.

\subsection{Pengujian Sistem Informasi}

Setelah dilakukan pengiriman data dari alat ukur ke database, dengan waktu interfal dari setiap pengiriman adalah 3 detik, dengan tujuan agar tidak terjadi penumpukan data. Dengan skenario pengiriman dari setiap perangkat adalah 1000 data, ternyata hanya 997 data yang masuk ke database sesuai dengan id_rumah dan id_data. 1000 data dari setiap masing-masing alat ukur terdapat 3 data yang hilang, dengan demikian dapat disimpulkan bahwa pengiriman data mempunyai nilai presentase error sebesar $0.3 \%$.

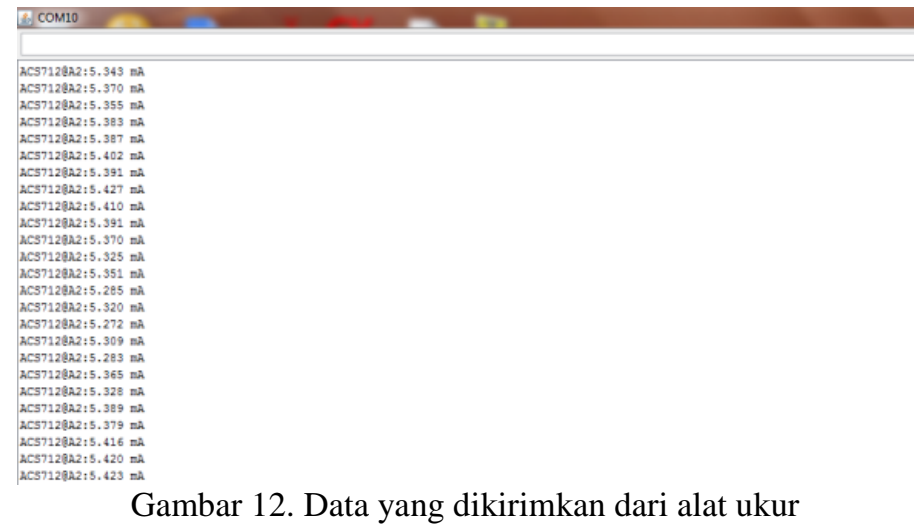

\subsection{Pengujian Akurasi Data}

Tabel dibawah merupakan tabel perbandingan antara data yang dikirim oleh alat monitoring daya dengan data yang diterima di database, untuk proses validasi data pengujian dilakukan dengan mengirim data dari alat ukur dengan id_rumah yang diberi nilai 007, dimana id_rumah 007 tidak terdapat pada database.

Tabel 4. Perbandingan data yang dikirim oleh Alat Monitoring dengan Data yang disimpandi Database

\begin{tabular}{|c|c|c|c|c|c|}
\hline No & id_rumah & $\begin{array}{c}\text { Data Yang dikirim } \\
\text { (Arus, Tegangan, Daya } \\
\text { nyata) }\end{array}$ & $\begin{array}{c}\text { Data yang diterima } \\
\text { (Arus, Tegangan, Daya nyata) }\end{array}$ & $\begin{array}{c}\text { Nilai } \\
\text { Kesalahan } \\
\text { (error value })\end{array}$ & $\begin{array}{c}\text { Validasi data } \\
\text { id_rumah }\end{array}$ \\
\hline $\mathbf{1}$ & 001 & $0.37,220,67$ & $0.37,220,67$ & $0.00 \%$ & sukses \\
\hline $\mathbf{2}$ & 001 & $0.38,220,68$ & $0.38,220,68$ & $0.00 \%$ & sukses \\
\hline $\mathbf{3}$ & 001 & $0.38,220,68$ & $0.38,220,68$ & $0.00 \%$ & sukses \\
\hline $\mathbf{4}$ & 001 & $0.37,220,69$ & $0.37,220,69$ & $0.00 \%$ & sukses \\
\hline $\mathbf{5}$ & 001 & $0.38,221,69$ & $0.38,221,69$ & $0.00 \%$ & sukses \\
\hline $\mathbf{6}$ & 001 & $0.38,221,68$ & $0.38,221,68$ & $0.00 \%$ & sukses \\
\hline $\mathbf{7}$ & 001 & $0.37,220,68$ & $0.37,220,68$ & $0.00 \%$ & sukses \\
\hline $\mathbf{8}$ & 001 & $0.37,220,68$ & $0.37,220,68$ & $0.00 \%$ & sukses \\
\hline $\mathbf{9}$ & 001 & $0.37,221,67$ & $0.37,221,67$ & $0.00 \%$ & sukses \\
\hline $\mathbf{1 0}$ & 001 & $0.38,221,67$ & - & - & ditolak \\
\hline $\mathbf{1 1}$ & 007 & $0.37,220,67$ & - & - & ditolak \\
\hline $\mathbf{1 2}$ & 007 & $0.37,220,67$ & - & - & ditolak \\
\hline $\mathbf{1 3}$ & 007 & $0.37,220,68$ & - & - & ditolak \\
\hline $\mathbf{1 4}$ & 007 & $0.37,221,67$ & - & - & ditolak \\
\hline $\mathbf{1 5}$ & 007 & $0.38,221,67$ & - & ditolak \\
\hline
\end{tabular}

Setelah dibandingkan antara data yang dikirim oleh alat monitoring daya dengan data yang diterima oleh database didapatkan hasil bahwa data yang diterima oleh database sesuai dengan data yang dikirim oleh alat monitoring daya. Sehingga dapat diambil kesimpulan bahwa database dapat menerima dan menyimpan data sesuai dengan yang 
dikirimkan oleh alat monitoring daya karena database mempunyai presentase error sebanyak $0 \%$,

Pengujian validasi diperoleh presentase sukses $100 \%$, karena pada proses validasi data yang dikirim dari alat ukur dengan id_rumah 007 ditolak, sehingga data dengan id_rumah 007 tidak terdapat pada database.

\section{KESIMPULAN dan SARAN}

\subsection{Kesimpulan}

Dari hasil pengukuran dan analisa yang telah dilakukan pada perancangan alat pengukur parmeter listrik satu fasa diambil kesimpulan sebagai berikut:

1) Hasil pengukuran pada nilai arus didapatkan nilai kesalahan rata-rata sebesar $3,28 \%$, pada pengukuran tegangan didapatkan nilai kesalahan rata-rata sebesar $0,39 \%$, sedangkan untuk pengujian daya didapatkan nilai kesalahan rata-rata sebesar $8,82 \%$.

2) Pengiriman data dari masing-masing perangkat pengukuran menuju web server sudah dapat terhubung dengan interval yang telah diatur selama 3 detik, data yang dikirim dan tersimpan di database, mempunyai nilai presentase error sebesar $0.1 \%$, dan akurasi data dari alat ukur ke database sebesar $100 \%$.

3) Proses validasi data memiliki akurasi $100 \%$, sesuai skenario pembuatan sistem dengan menolak data id_rumah apabila tidak sesuai dengan yang terdapat pada database.

\subsection{Saran}

1) Pada pengukuran tegangan sebaiknya menggunakan modul sensor tegangan yang lebih baik, karena pengukuran tegangan yang menggunakan trafo CT yang menimbulkan panas jika dilakukan pengukuran dalam waktu yang lama dan dapat menyebabkan perhitungan tegangan yang tidak valid.

2) Nilai kesalahan pada pengujian pengukuran arus berasal dari nilai toleransi yang dimiliki setiap komponen, seperti pada resistor, kapasitor dan yang lainnya, sebaiknya digunakan komponen-komponen yang memiliki nilai toleransi yang kecil, dan tetap stabil meskipun dalam kondisi panas.

\section{Daftar Pustaka}

[1] Rohman, Yanuar. Rancang Bangun Sistem Pengukuran Arus Berbasis Mikrokontroller Atmega 8535. Politeknik Elektronika Negeri Surabaya, https://www.pens.ac.id/uploadta/downloadmk.php?id=1136, diakses 9 November 2015, 20:18.

[2] Itmi Hidayat Kurniawan, Latiful Hayat. 2014 .Perancangan dan Implementasi Alat Ukur Tegangan, Arus dan Frekuensi Listrik Arus Bolak-Balik Satu Fasa Berbasis Personal Computer. Techno, ISSN 1410 - 8607, Volume 15 No. 1.

[3] Cahyani. A, Soeprapto, Ir. Soemarwanto. 2014 .Studi Analisis Pengaruh Harmonisa Beban Nonlinier Rumah Tangga Terhadap Hasil Penunjukan kWh Meter Digital 1 Fasa. Malang. Universitas Brawijaya.

[4] Ronald Ambatoho P. Gorat, Dr. Ir. Edi Leksomo M.Eng dan Ir FX Nugroho Soelami. 2013. Perancangan sistem pemantauan energi listrik pada bagunan secara waktu nyata berbasis web. Jurnal Tugas Akhir Sarjana Fakultas Teknologi Industri ITB Vol.II No. 1.

[5] Basic Electrical Engineering, Part 11: Power in AC Circuits. http://www.itacanet.org/basicelectrical-engineering/part-11-power-in-ac-circuits/. diakses 21 Oktober 2015, 10:24. 
[6] Reactive Power. http://www.electronics-tutorials.ws/accircuits/reactive-power.html. diakses 21 Oktober 2015, 10:47.

[7] Bloom J. 2013 .Exploring Arduino, tools and techniques for engineering wizardry. Wiley.

[8] YHDC SCT-013-000 Current Transformer.

http://openenergymonitor.org/emon/buildingblocks/report-yhdc-sct-013-000-currenttransformer. diakses 26 Oktober 2015, 21:13.

[9] Problem with current transform SCT-013-000. http://openenergymonitor.org/emon/node/10044. diakses 26 Oktober 2015, 21:15.

[10] WiFi Shield V2.2 for Arduino from DFRobot - WizFi210. http://wiznetmuseum.com/portfolio-items/wifi-shield-v2-2-for-arduino-from-dfrobotwizfi210/. diakses 5 Oktober 2015, 13:16.

[11] Jogianto2 HM. 2005 .Sistem Teknologi Informasi. Andi. Yogyakarta.

[12] Highcharts. http://www.highcharts.com/. diakses 18 Agustus 2015, 18:47. 